\title{
Russian Youth Entrepreneurship in the Context of Three Approaches
}

\section{Svetlana Anatoljevna Ilynykh}

\author{
Tomsk State University, 36 Lenin Ave., Tomsk 634050, Russian Federation
}

Email: ili.sa@mail.ru

\section{Doi:10.5901/mjss.2015.v6n4s4p381}

\begin{abstract}
This article reveals approaches to youth entrepreneurship from the perspective of economic, socio-psychological and sociological aspects. From economic perspective, young people's interest for business activity is connected with such an economic motive as property right, right to ownership, right to disposal and right to income control. Socio-psychological approach allows considering inner psychological regulators of young entrepreneurs' economic behavior. From sociological perspective, young entrepreneurs interact closely with the state, have unconventional economical behavior, and possess personal traits that may bring to social changes. Theoretical ideas are illustrated by the results of the empirical research conducted in Novosibirsk, Tomsk and Ufa.
\end{abstract}

Keywords: entrepreneurship, youth entrepreneurship, gender.

\section{Introduction}

Development of entrepreneurship in general and youth entrepreneurship in particular is an extremely important process for the development of the Russian society. It is connected with the fact that business class is the one which plays the major role in the improvement of standard of living, quality of products and provided services. According to the Institute of Sociology, Russian Academy of Sciences, a number of changes have taken place in the social structure of post-reform Russia. It turned out that from 2003 till 2010 percentage of the "business class core" increased from 11\% to 15\%. However for sustainable development of the society, for its stability, the amount of necessary percentage is $30 \%$ (Gorshkov, 2011).

The World Bank conducted research which proved that if in a country less than $40 \%$ of GDP falls to small and medium-sized enterprises, then investment into economy of this country will not lead to the targeted economical effect. This is a further proof that support of entrepreneurship is highly important. Youth entrepreneurship serves here as a relevant strategic resource for development of small and medium enterprises.

Development of small business, including youth entrepreneurship, is essential with regard to the creation of new vacancies as well as for the purposes of economic benefit that enables to enter into rivalry with big business on the market. Such benefit comprises fast cash cycle; cost cut due to decrease of expenditures for maintenance of the executive office; administrators' free play; staff replaceability; flexibility, ability to adapt and adjust to changing conditions; perceptivity of innovation activity; capability to take the risk. These and some other characteristics of small enterprises give them principal privileges. Youth entrepreneurship plays a major role in solving socio-economic problems, such as job creation, decrease of unemployment rate, training of skilled personnel (Blinov, 2013).

Youth entrepreneurship carries out a number of functions of social importance that are peculiar to the spheres of youth and social policy: to form a new national mentality that is based on positive relation to the institute of private property and entrepreneurship; increase young adults' economic activity; organize young adults' employment; provide orientation training and education for young people; give an opportunity to unlock young adults' high educational potential, their self-actualization and self-esteem; improve young people's standard of living; form active social position of the youth; strengthen social protection of the youth (Pozdnyakov, 2012, p. 522).

From our point of view, development of youth entrepreneurship is a sufficiently long process. It is connected with a variety of factors. They may include those that are distinguished by researchers in relation to entrepreneurship as a whole: imperfection of the normative legal base; absence of efficient financial and credit mechanisms as well as material and resource provision; imperfection of the tax system and state support system; administrative barriers and others (Raksha, 2013, p. 3). For a much deeper view into peculiarities of youth entrepreneurship, we offer its interpretation in the context of three approaches. 


\section{Literature Review}

In the $20^{\text {th }}$ century entrepreneurship is treated not only as an economic phenomenon, but also as a social and legal phenomenon. M. Veber's ideas about entrepreneurship, which are based on belief that people are predisposed to a particular type of practical rational behavior, contributed significantly to inclusion of the social component (Veber, 1990). At the same time scientific interpretation of entrepreneur's personal qualities appeared (Druker, 1992). A. Khosking (Khosking, 1993) supposes that an entrepreneur is a person that runs their own business self-dependently and at their own expense, bears personal responsibility for provision of necessary resources, and makes decisions all by themselves. Their reward is the profit that they gain as a result of their business operations and a feeling of satisfaction that they get from the involvement into the free enterprise. Alongside with that, however, they have to take chances in case of business failure.

In their work "Economics" K. McConnell and S. Brue continued research of that topic (McConnell, Brue, 2006). Researches gave a definition to a term "entrepreneurship" through the following four entrepreneur's functions: 1 . The entrepreneur takes up the initiative in order to connect earth, capital and labour resources into one whole process of production of goods and services. Playing a quasi-role of a spark plug and accelerant, an entrepreneur acts as an engine of production growth and a mediator that brings together all resources to finish the process which promises to be profitable business. 2. The entrepreneur is responsible for the process of decision-making while running business, for all main decisions that determine enterprise profile. 3. The entrepreneur is a pioneer, a person who strives to put new products, new technologies and even new forms of business organization into practice on the commercial basis. 4 . The entrepreneur is a person who is ready to take up the risk.

J. Shumpeter and T. Parsons made their contribution into the interpretation of the term "entrepreneurship" and its social functions (Shumpeter, 1982; Parsons, 2002).

Formation and development of entrepreneurship in Russia led to the appearance of special interdisciplinary research, devoted to entrepreneurs' status positions in the society, their place and role in the social structure. Among researchers in this sphere Z. Golenkova (Golenkova, 1998) and T. Zaslavskaya (Zaslavskaya, 1995) are worth mentioning.

In the $21^{\text {st }}$ century researchers have taken a deeper view into effectiveness and risks of the enterprise activity (Savitsskaya, 2011), organizational aspects of enterprise development (Nersisyan, 2011) management of small enterprises (Sheremet, 2012), perspectives of small business (Khvostikov, 2012).

We suppose that in the sociological context, the phenomenon of youth entrepreneurship may be studied on the basis of several methodological approaches: economic, socio-psychological and sociological.

From economic perspective, youth entrepreneurship is connected with property in the proper sense of this word. To analyze the problem of youth entrepreneurship in greater detail, we will draw on a much broader notion entrepreneurship, and then interpret it with regard to youth entrepreneurship.

Considering entrepreneurship in the context of property, we may say that it has a particular development path. Historically public property took the premier place. One of the greatest socialist and utopianist R. Owen experimentally stated the role of such factors as readiness of people's consciousness, industrial management, work discipline, distribution structures in the organization, functioning of domestic industrial associations based on public property (Owen, 1951, p. 47). Here the aspect of readiness of the consciousness for social transformation in the form of public property may be distinguished.

On a brand new level, the category of "property" has become a subject for study in K. Marx' and F. Engels' works. In their writings Marxism founding fathers came to a conclusion that property is a general economic phenomenon that was typical for all historical stages of social development. They proved that in every socio-economical formation property acquires specific and simultaneously dominant forms in the observation of "social equity" principle, development of ideology, political and economic institutions, relations in the social structure of the society (Marx, Engels, 1955, p. 88). Marxism founding fathers had no doubt that the category of property evolved from simple economic relations between people concerning things to its understanding as a whole socio-economic life condition of all members of the society.

Considering this classis authors' thesis to be fundamental in the context of entrepreneurship, we may claim that property represents a socio-economic condition of entrepreneurs' life. In other words, an entrepreneur is always an owner of proprietary rights. O.E. Ryazanova offers the following classification of proprietary rights: right to use, including management of proprietary subject matters; right of ownership that presupposes the enterprise use of proprietary subjects; right to create goods, and at last, right to dispose, including control of income flows (Ryazanova, 2009).

Summing up all the ideas stated above, it is worth mentioning that property right is not the only economic incentive for the development of youth entrepreneurship, but also right of ownership, right to dispose and right to control earnings. 
This idea was proved in the empirical research, conducted by the author in Novosibirsk in 2015 ( $N=434)$. Answering the question "What makes business attractive?", respondents delivered that their own business attracts them by permanent employment, acquirement of new skills, high income and an opportunity to manage funds. We dwell on results of the research later.

In the introduction we highlighted the correlation between entrepreneurship and the size of the middle class. The indicating factor of income, which entrepreneurship yields, directly correlates with the size of the middle class. For instance, American researchers N. Birdsall, K. Graham and S. Pettinato use indicators of population income to characterize the middle class in different countries and to estimate its size. They explain their choice by the reason that this criterion allows to register change of the size of the middle class with the course of time (Birdsall, Graham, Pettinato, 2000). The higher the level of entrepreneurs' income is, the steadier the boundaries of the middle class are. Research of the middle class from various perspectives is represented in N.E. Tikhonova's and N.I. Lapin's writings (Tikhonova, 2006, 2008; Lapin, 2003).

From socio-psychological perspective entrepreneurship, in the aspect of property availability, presupposes that a subject of relations is represented by not just an individual, but an individual that lives in a particular society. An entrepreneur socializes and is being brought up in a particular social stratum, group or cluster. Besides, an entrepreneur enters into social relations between subjects of property. Subject-subject interaction between entrepreneurs is determined by history, culture and character of a particular society (Popov, 2008, p. 19). Bearing these ideas in mind, we may conclude that a young entrepreneur socializes in peculiar historic conditions, which leave an imprint on his/her relations with other subjects of property.

Socio-psychological approach gives an opportunity to take inner psychological regulators of entrepreneurs' economic behavior into consideration. To such regulators belong: honesty, entrepreneurial spirit, thrift, as well as dishonesty, wastefulness, carelessness. Among such dichotomic entrepreneurs' qualities N.G. Khvesyuk distinguishes the following: empathy and indifference; involvement and detachment; honesty, decency and thievery, impudence, cynicism; reasonable thrift and avarice; competent initiativity and "Russian maybe"; a sense of ownership and mismanagement; team spirit and indifference; self-discipline and carelessness; collectivism and individualism, priority of personal interests and alienation from the public ones; care for welfare of others and greed, self-centeredness (Khvesyuk, 2014, p. 60). The author makes an assumption that it is advisable to measure the level of dichotomy of these qualities which the entrepreneurs' class possess. If an owner is not put within the boundaries of ethics, justice and interests of the whole society, then their economic behavior may transform into such behavior patterns as: greed, passion for illicit gain, deception, bribery, theft, deceit, cruelty. In pursuit of the great desire to turn into a man of property, their main principle of life may become the motto "all's fair in love and war, especially if it yields profit".

As for youth entrepreneurship, nowadays one of the main reasons of its suppressing is a negative image of an entrepreneur. According to the opinion poll, such an image is connected with passion for illicit gain, dishonesty, unscrupulousness, and consumer attitude to people (Chervyakov, Cherednichenko, Shapiro, 1992). In the meantime, positive and negative evaluations split fifty-fifty: $51 \%$ and $49 \%$ respectively. Positive evaluations deal with business qualities, whereas negative ones characterize a moral businessman's portrait.

Dwelling upon youth entrepreneurship, it is worth dividing entrepreneurs into groups or strata, as entrepreneurs in general and young businessmen in particular are heterogeneous.

In $90^{\prime}$ s of the $20^{\text {th }}$ century scientists have classified young entrepreneurs into four strata (Rakovskaya, 1989). First stratum has come out of the sphere of shadow economy. As a rule, they started to run business pretty early, even without any profession. At school they learnt to "make money", being involved into re-selling clothes, cosmetics and western electronic devices. Saving up enough capital, they set up officially registered companies. A distinctive feature of the representatives of this stratum is a high level of claims which determines the choice of business sphere - mediation activity, trading and purchasing, providing services in the sphere of "commercial tourism".

Second stratum consists of entrepreneurs out of the nomenclative and komsomol environment. They have made a successful career in lower sectors of party and komsomol structures. Representatives of komsomol structures are distinguished by a business-like character, a wide informal chain of relations and organizing skills. This elite group of entrepreneurs occupies the most stable business niches.

Primary objectives are chief's career, high social status and high level of material wealth. Means of reaching life goals are personal relations and ability to interact with people.

Third stratum includes entrepreneurs out of the scientific sphere: these are young people who are aimed at obtaining a profession. Professionalism is the major value. As a rule, they belong to intelligent families, and their parents are specialists and masters of their craft. Those "scientific" entrepreneurs opt for business for different reasons: they want to have an opportunity to devote time to scientific research or their favourite hobby. For representatives of this stratum, 
business is a temporary activity. A special connection between generations is one of the characteristics. On the one hand, a family has a great influence on the choice of a profession, sphere of interests, moral values and social directions. On the other hand, children's social behavior may represent a challenge to parents' way of life and their social values. Entrepreneurs are "scientists" who claim that business is a step backwards, retrogression in relation to their potential possibilities.

Fourth stratum comprises entrepreneurs, whose parents belong to the military or industrial system in view of their occupation or place of employment. This stratum is characterized by strong bonds between generations. Here dominant factors are orientation on the cult of the family clan, life for themselves and their parents, continuation of the family business. The way of achieving life purposes lies through mastering the occupation. Professionalism plays a decisive role in career.

Young entrepreneurs of this type are engaged in production or greatly oriented on it. Moderation, consistency, regularity in achieving life goals, focus on the production and professionalism, high social status and material wealth these are the characteristics of representatives' mindset in this stratum.

The first and second strata occupy dominant positions. Young entrepreneurs are attracted by those spheres of business activity that promote rapid capital turnover, high profitability, but do not provide the population of the country with goods and services. That means the choice of the simplest and fastest ways of gaining profit (mediation activity, selling and purchasing, stock-exchange and banking industry), i.e. hypertrophy of the sphere of distribution in opposition to the sphere of production. In other words, young entrepreneurs do not have a clear-cut focus on the innovative activity and perspective.

Nowadays this type of young entrepreneurs is no longer so widespread. However, some methods of recruitment into strata of young entrepreneurs exist till now, for example, the stratum of young entrepreneurs that initially belong to scientists. There is no doubt that types of modern Russian young entrepreneurs should be studied separately and in more detail.

It is worth mentioning that from sociological perspective, youth entrepreneurship in a broad sense needs to be interpreted from four perspectives: as a social entrepreneurs' group that has mechanisms of social interaction with the state; as a social phenomenon that shows itself in the form of unconventional economic behavior that is typical for an entrepreneur; as a subject of a social system which possesses traits that are formed on the basis of individual innovativity; as a source of social changes that is cumulated in entrepreneurs' pioneer activity (Raksha, 2013, p. 12).

\section{Material and Methods}

All the ideas about entrepreneurship that were stated above have been proved in our empirical studies which were conducted in 2015 in Novosibirsk, Tomsk and Ufa. Study of youth entrepreneurship represents scientific interest, thus it is possible to determine similarities and differences in various regions of Russia. One of the regions is Siberia that is represented by Novosibirsk and Tomsk; another is Ural that is represented by Ufa.

Young people at the age of 18-25 took part in the empirical research. Study population comprises 434 respondents in Novosibirsk, 596 - in Tomsk, 600 - in Ufa. A mass semi-formalized face-to-face interview with students of senior courses at the universities of the mentioned cities was chosen as a data-collection method. We are talking about semiformalization, because apart from quantitative questions, motivation questions were included in the interview paper as well. Such questions give the possibility to reveal respondent's attitude, as the interviewer fixes answers in the lexical form in which they we given. Hereafter we carried out the semantic analysis of statements about individual motivations.

\section{Discussion}

Within this article we clarify such aspects of the sociological approach to entrepreneurship as collaboration with the state and peculiar entrepreneurs' character traits which determine their unconventional economic behavior that serves as a source of social changes.

Collaboration with the state

We should indicate that in our study we have not intended to analyze the state policy as it is, because our main research objective is to define respondents' opinion about this factor.

It turned out that one third of the respondents point out a significant influence of the state policy on the enterprise development. It is necessary for the respondents to get services from the state in order to implement their business project. Having analyzed the answers to the question about necessary state services, we have found out that the respondents are of the same mind about obtaining of such services: 
- training and consultation in questions of entrepreneurship (59\% of men and $70 \%$ of women in Novosibirsk, $40 \%$ of men and $42 \%$ of women in Tomsk; $54,9 \%$ of men and $61,4 \%$ of women in Ufa);

- legal services that deal with setting up and running business, as well as solving controversial problems (59\% of men and $70 \%$ of women in Novosibirsk, $32 \%$ of men and $33 \%$ of women in Tomsk; $45,4 \%$ of men and $50,0 \%$ of women in Ufa);

- granting subsidies and security for credit (31\% of men and $34 \%$ of women in Novosibirsk, $28 \%$ of men and $31 \%$ of women in Tomsk; $40,8 \%$ of men and $38,9 \%$ of women in Ufa).

Differences in young respondents' opinions in questions about state services are the following:

- search of business partners ( $42 \%$ of men and $36 \%$ of women in Novosibirsk, $27 \%$ of men and $21 \%$ of women in Tomsk; $26,1 \%$ of men and $30,4 \%$ of women in Ufa);

- delivery of information in questions of entrepreneurship including Internet-resources (35\% of men and $31 \%$ of women in Novosibirsk, $15 \%$ of men and $17 \%$ of women in Tomsk; $25,0 \%$ of men and $19,6 \%$ of women in Ufa);

- organization of traineeships in the Russian regions and abroad (24\% of men and $39 \%$ of women in Novosibirsk, $33 \%$ of men and $38 \%$ of women in Tomsk; $41,9 \%$ of men and $50,3 \%$ of women in Ufa).

As we see, the search of business partners is more relevant for respondents from Novosibirsk. The number of respondents from Tomsk and Ufa is around half as less again.

Delivery of information generates more interest on the part of young respondents from Novosibirsk, and less interest on the part of the respondents from Tomsk.

As for organization of traineeships for young entrepreneurs in Russia and abroad, here a greater amount of women is obvious. Women from Ufa share their opinion two times more often compared to men form Novosibirsk.

All in all, we can conclude that young potential entrepreneurs in the first place need trainings in business running that deals with economic, legal and other aspects.

It should be stated that one of the aspects of state support of entrepreneurship is the creation of IT environment that is favorable for studying and exchange of experience in the enterprise sphere. It turned out that in Novosibirsk only $18 \%$ of men and $12 \%$ of women know that special trainings, workshops and courses are held and aimed at elaboration and implementation of innovation projects. 33\% of men and 35\% of women have heard something about it. To compare: in Tomsk $15 \%$ of men and $5 \%$ of women are informed of that, and $31 \%$ of men and $24 \%$ of women have heard about it. It is clearly that the situation is almost the same in all three cities.

It is worth noticing that such seminars and trainings actually exist, and there is public access to relevant information in network systems of public authorities. The fact that only one fifth of the respondents are aware of it implies that they are not able to find necessary information themselves.

However, there are still some young respondents who have already used state services: $11 \%$ of men and $7 \%$ of women in Novosibirsk, $2 \%$ of men and $0,3 \%$ of women in Tomsk.

It is telling that in Ufa answering the question "Do you know anything about regional programs of support of the youth business-project?" almost half of the respondents admitted their awareness (53,9\% and $49,7 \%$ respectively). However, answering the question "In your opinion, how effectively do entrepreneurs in your region use programs of business support?" the majority of the respondents say "most likely, not so effectively" (43,7\% and 35,8\% respectively).

Entrepreneur's character traits

As stated above, according to the sociological approach, entrepreneurship should be considered with regard to unconventional economic behavior, taking special personal characteristics into account, and initiativity in particular, that serves as a source of social changes.

To make this aspect clear, respondents evaluated such qualities as active performance, initiativity, ability to take the risk, ability to present oneself, carefulness, severity, self-confidence, responsibility.

It turned out that young respondents from Novosibirsk put self-confidence on the first place (93\% of men and 91\% of women), on the second place - active performance (93\% of men and $90 \%$ of women), on the third place responsibility ( $91 \%$ of men and $90 \%$ women), on the fourth place - initiativity ( $82 \%$ of men and $78 \%$ of women), on the fifth place - ability to take the risk ( $62 \%$ of men and $56 \%$ of women). Answers, which respondents gave in Tomsk, almost coincide: on the first place - self-confidence ( $77 \%$ of men and $75 \%$ of women), on the second place - active performance ( $71 \%$ of men and $75 \%$ of women), on the third place - responsibility ( $70 \%$ of men and $69 \%$ of women), on the fourth place - ability to take the risk ( $62 \%$ of men and $63 \%$ of women), on the fifth place - initiativity (60\% of men and $60 \%$ of women). As we see, in both groups character traits were put in the same order. However, initiativity takes the fourth place in Novosibirsk, whereas in Tomsk - only the fifth place. We may suggest that in respondents' consciousness the meaning of the word "initiativity" is not as significant as in case with, for example, ability to take the risk or active 
performance.

Own business: true-to-life picture

We asked the respondents: "Do you intend to set up your own business or become a part of a new one? Perhaps, you've already been participating?" (table 1). This question allowed us to draw certain conclusions about the true-to-life picture of youth entrepreneurship.

Table 1 - Distribution of answers to the question "Do you intend to set up your own business or become a part of a new one? Perhaps, you've already been participating?" (in \% of all respondents in the region)

\begin{tabular}{|c|c|c|c|c|c|c|}
\hline \multirow{2}{*}{ Possible answers } & \multicolumn{2}{|c|}{ Novosibirsk } & \multicolumn{2}{|c|}{ Tomsk } & \multicolumn{2}{|c|}{ Ufa } \\
\hline & male & female & male & female & male & female \\
\hline Yes, I've already set up business / taken part in new business & 12,6 & 2,5 & 7,7 & 1,6 & 10,9 & 3,8 \\
\hline Yes, I am eager / ready to set up my own business or participate in new business & 42,6 & 38,5 & 44,2 & 39,2 & 39,4 & 37,3 \\
\hline I haven't thought about it / I haven't decided yet & 40,5 & 54,9 & 23,2 & 30,2 & 42,1 & 50,3 \\
\hline No, I don't consider such a possibility & 4,2 & 4,1 & 24,9 & 28,9 & 8,5 & 8,5 \\
\hline
\end{tabular}

It turned out that not only potential entrepreneurs but also real young businessmen have taken part in the poll. It is telling that the number of male-businessmen is the greatest in Novosibirsk, and female-businessmen - in Ufa. It is important that around $40 \%$ of respondents of both genders in three cities would like to set up their own business or become a part of new business. We may consider them as potential young entrepreneurs. It is a different matter that it may have nothing in common with real business in the future. It is interesting that the percentage of actual businessmen in Tomsk is the lowest, and with that the amount of respondents who would like to start their own business is higher than in Novosibirsk or Ufa.

It is also worth noticing that in Tomsk the number of respondents who have not even thought of their own business is half as many as in the other cities. Situations in Novosibirsk and Ufa are almost similar.

Meanwhile, it is telling that the greatest number of the respondents who do not even consider such a possibility is again in Tomsk. Thus, in Novosibirsk $4 \%$ of men and women are of the same opinion, that is twice as little as in Ufa - $8 \%$ (men and women). In Tomsk - 24,9\% of men and $28,9 \%$ of women.

As we questioned young adults who have flexible cognitive constructions, we are not able to draw far-reaching conclusions. We may only assume that around $42 \%$ of men and $38 \%$ of women all together are ready to set up their own business. Alongside with that, one third of the respondents in Tomsk and less than $10 \%$ of the respondents in the other cities have not even considered this possibility.

\section{Conclusions}

It is important to analyze youth entrepreneurship in Russia in the context of three approaches. From economic perspective, young people's interest for business activity may be connected with such an economic motive as property right, right to ownership, right to disposal, and right to income control. Socio-psychological approach allows considering inner psychological regulators of young entrepreneurs' economic behavior. From sociologic perspective, young entrepreneurs closely collaborate with the state, have unconventional economic behavior and possess personal traits that serve as a source of social changes. In the sociological research that has been conducted in Novosibirsk, Tomsk and Ufa all mentioned young entrepreneurs' peculiarities have been studied. We have analyzed gender peculiarities as well. Gender issues were studied by following authors: K. West and D. Zimmerman (West, Zimmerman, 2000), T. Lauretis (Lauretis, 1987), Y. Hirdman (Hirdman, 1991). Results of gender research may be found in S.A. Il'inikh's works (Il'inikh, $2009,2012)$. However, this topic is so vast that it is worth of special mention.

\section{Acknowledgements}

This research project (research grant No 8.1.98.2015) was supported by the Tomsk State University Academic D.I. Mendeleev Fund Program in 2015.

\section{References}

Birdsall, N., Graham, C., Pettinato, S. (2000). Stuck in the Tunnel: Is Globalization Muddling the Middle Class? // Carnegie Endowment 
for International Peace. Discussion Paper No 1.

Blinov, A.O. (2013). Maloe predprinimatel'stvo kak problema regional'nogo razviitiya // Entopoliticheskii vestnik, 4, 17-23.

Chervyakov, V.V., Cherednichenko, V.A., Shapiro, V.D. (1992). Rossiyane o predprinimatel'stve i predprinimatelyakh // Sotsiologicheskie issledovaniya, 10.

Druker, P. (1992). Novovvedeniya i predprinimatel'stvo // Problemi upravleniya ekonomikoj, 23. M.

Golenkova, Z.T. (1998). Dinamika sotsiostrukturnoj transformatsii v Rossii // Sotsiologicheskie issledovaniya, 10, 24-38.

Gorshkov, M.K. (2011). Rossijskoe obshchestvo kak ono est'. M.

Hirdman, Y. (1991). The Gender System I/ T. Andreasen, et al. (eds.). Moving on. New Perspective on the Women's Movement. Aarhus Univ. Press. (208-220).

Il'inikh, S.A. (2009). Gendernaya kontseptsia organizatsionnoi kul'turi: monografiya. Novosibirsk.

Il'inikh, S.A. (2012). Gendernaya teoriya upravleniya // Idei i ideali. Vol. 1, 2 (12), 115-126.

Il'inikh, S.A. (2012). Zhenskij top-menedzhment s tochki zreniya sotsiologii upravleniya // Vestnik NGUEU, Vol. 2, 4, 113-123.

Khosking, A. (1993). Kurs predprinimatel'stva. M.: Mezhdunarodnie otnosheniya.

Khvesyuk, N.G. (2014) Razvitie sotsial'nikh otnoshenij v korporatsiyakh v usloviyakh reformirovaniya rossijskogo obshchestva: avtoref. dis... d-ra sotsiol. nauk. M.

Khvostikov, A.G. (2012). Malij biznes v Rossii: perspektivi i nadezhdi // Rossijskoe predprinimatel'stvo, 2 (200), 97-100.

Lapin, N.I. (2003). Kak chuvstvuyut sebya, k chemu stremyatsya grazhdane Rossii // Sotsiologicheskie issledovaniya, 6, 78-87.

Lauretis, T., (1987). The Technology of gender: Theories of representation and difference. Bloomington: Indiana University Press.

Marx, K. (1995). Ekonomichesko-filosofskie rukopisi 1844 // Marx K. i Engels F.. Soch. 2-e ed., Vol. 42.

McConnell, K., Brue, S. (2006). Economics. Baku: Azerbaidzhan, 2006.

Nersisyan, G.Y. (2011). Razviitie predprinimatel'stva: organizatsionnij aspect. M.: Ankil.

Owen, R. (1951). Izbrannie sochineniya. Vol. 1-2. M. - L.

Parsons, T. (2002). Sotsial'noe dejstvie i usloviya chelovecheskogo sushchestvovaniya. M.: AST-LTD.

Popov, V.D. (2008). Paradigmi issledovaniya informatsionnikh protsessov. M.: RAGS.

Poznyakov, V.P. (2012). Predpinimatel'stvo kak tsennost' i tsennosti rossijskikh predprinimatelej // Rossia v globaliziruyushchemsya mire: mirovozrencheskie tsennosti i sotsiokulturnie aspekti. M: Nauka.

Rakovskaya, G.A. (1989). Sotsial'nie i ekonomicheskie orientiri molodogo pokoleniya (teoriya, metodologiya, analiz): Avtoref. dis. M.

Raksha, I.R. (2013) Gosudarstvennaya podderzhka innovatsionnogo malogo predprinimatel'stva v regione: avtoref. dis... kand. sotsiol. n. Tyumen.

Ryazanova, O.E. (2009). Transformatsiya otnoshenij sobstvennosti v usloviyakh globalizatsii ekonomiki: avtoref. dis... d-ra ekon. nauk. M.

Savitsskaya, G.V. (2011). Analiz effektivnosti i riskov predprinimatel'skoi deyatel'nosti. M.: INFRA-M.

Sheremet, A.D. (2012). Maloe predprinimatel'stvo: organizatsiya, ekonomika, upravlenie. M.: INFRA-M.

Shumpeter, J. (1982). Teoriya ekonomicheskogo razvitiya. Per. s nem. / Pod. red. A.G. Milejkovskogo. M.: Progress.

Tikhonova, N.E. (2006). Gorodskoj srednij klass v sovremennoi Rossii. Analiticheskij doklad Instituta sotsiologii RAN. M.

Tikhonova, N.E. (2008). Srednij klass v sotsiologicheskom izmerenii // Diskussiya o srednem klasse / INSOR, M.: Nauchnaya Kniga.

Veber, M. (1990). Izbrannie proizvedeniya. M.

West, K., Zimmerman, D. (2000). Sozdanie gendera // Khrestomatiya feministskikh tekstov. Perevodi. Pod. red. E. Zdravomislovoi, A. Temkinoi. Spb.: Izdatel'stvo "Dmitrii Bulanin", 193-220.

Zaslavskaya, T. (1995). Biznes-sloi rossijskogo obshchestva: sushchnost', struktura, stasus // Obshchestvennie nauki i sovremennost', $3,3-12$. 